\title{
THE POTENTIAL OF LIQUEFACTION DISASTERS BASED ON THE GEOLOGICAL, CPT, AND BOREHOLE DATA AT SOUTHERN BALI ISLAND
}

\author{
I Nengah Sinarta*, I Wayan Ariyana Basoka \\ Warmadewa University, Indonesia
}

Following the incident in Petobo, Palu, liquefaction becomes an essential object for in-depth study. Based on soil investigation by the CPT (cone penetration test) in site soil test has been carried out at Jalan Taman Pancing, the area of Southern Bali Island was analyzed for liquefaction potential using geological interpretation and soil properties. Deterministic analysis using Stress Based Method, using the 2017 Seismic Hazard Map of Indonesia for Bali island where the earthquake acceleration reaches $0.4-0.5 \mathrm{~g}$, meaning that Bali is highly vulnerable to earthquake, with the largest earthquake magnitude is the Mount Agung eruption measuring six on the Richter scale on May 18, 1963. The soil investigation shows that the layers of soil consist of sandy silt and silty clay at a depth between $0.5-12.0 \mathrm{~m}$ and $2 \mathrm{~m}$ water table, geological conditions with the Qa code alluvium deposits from ancient Buyan-Beratan Mountains. Deterministic analysis based on the CPT data and local geological conditions indicates that the thickness of the soil varies between $1.5 \mathrm{~m}$ and $9.5 \mathrm{~m}$, while the safety factor of the liquefaction potential is in the critical conditions between $1.25-1.00$.

Key words: geological, CPT, liquefaction, deterministic analysis

\section{INTRODUCTION}

Geological disasters pose a major hazards to Indonesia in 2018, with successive disasters occurring in Lombok and Central Sulawesi, specifically in Palu and Donggala. That is because Indonesian is located on the Ring of Fire, which is a zone of colliding plates. That is confirmed by the statement that said $90 \%$ of earthquakes and $81 \%$ of the largest earthquakes are recorded in the Ring of Fire. As the result, the Ring of Fire is also known as the Ring of Earthquake.

United State Geological Survey (USGS) [1], stated that around $90 \%$ of earthquakes in the world occur in the circum-Pacific belt, which is also a Ring of Fire. Then the other $5 \%$ to $6 \%$ is in the Alpide belt which expands from the Mediterranean to Turkey, Iran, and North India. Because the Ring of Fire and the Ring of Earthquake claimed millions of lives, the region is also called the Ring of Tragedy.

One of the consequences of geological disasters is liquefaction, which causes buildings to sink, collapse, or tilt, soil cracks, landslides, and so on. An example of the impact of liquefaction is the damage from the Bengkulu earthquake in 2000, the Aceh earthquake in 2004, the Nias earthquake in 2005, the Yogyakarta earthquake in 2006, and the Palu earthquake in 2018.

According tolshihara and Ansal [2], there are two factors that influence the threat of liquefaction on sand deposits: the level of sand density and the intensity of shocks during the earthquake. Serious attention to liquefaction disasters arises after earthquakes hit Niigata (1964) and Alaska (1964). The Niigata earthquake that occurred on June 16, 1964, has a magnitude of 7.5 and caused severe damage to several structures in Niigata, such as the collapse of the Showa Bridge pile foundation and the collapse of apartments in Kawagishi Town [3].

In the 2017 Indonesian Seismic Hazard Map[4]issued by the Ministry of Public Works, Bali has earthquake acceleration 0.4-0.5 $\mathrm{g}$ which means Bali is very vulnerable to an earthquake. Seismic activity in South Bali is caused by subduction of the Australian and Eurasian plates, while the activities of shallow active faults occur locally in the North and Northeast of Bali Island. Some indications show similar phenomena also occur in the Northwest-Southeast and West-East of Bali. Some areas have sedimentary soils, which is very problematic since they, just like peat, have high compressibility and weak shear strength, which need long-term improvement efforts [5].

The research shows that liquefaction occurs in the depth of $3 m-15 m$ for Seed et al (1976) method whereas no indication of liquefaction shows from Castro (1975) methods in any depths. [6]

Geological conditions and regional morphology heavily influence liquefaction hazards. To find out more about it, a test in the field is conducted using CPT, borehole test, and observation of groundwater level. Observations can determine the extent of distribution and depth, and find out the relation between the thickness of the liquefied layer and the local geological conditions, which can be used to predict the zone vulnerable to liquefaction. 


\section{MECHANISM OF DISASTER THREATS AND LIQUEFACTION}

Disaster mitigation urgently needs hazard maps, which are made with weighting parameter methods. If the figures have been recommended by the government, they should be modified according to the characteristics of the study area, beginning with geotechnical observations and investigations. The experience of individuals who do the weighting also influences the modification of the weights scale on each parameter. Therefore, this method is actually subjective [7]. Volcanic ash containing silica that has been bound by weathered rock and mixed with water has the potential to accelerate the occurrence of soil movements and alluvial soil deposits [8].

Geological conditions strongly influence the threat of disasters such as landslides, in which the characteristics of matrix saturated clay contribute to the speed of movement and distance of avalanche in volcanic rock areas, and landslides have 2 characteristics: (1) subsidence and (2) material flow (debris flow), which form a crook on steep slopes [9].

The mechanism of liquefaction is observed from the soil in the area as illustrated in Figure 1. When there is no influence from an earthquake, the effective vertical stress in soil is $\sigma^{\prime}$ ' 'or equal to total stress $\left(\sigma_{y}\right)$, and the effective horizontal stress in soil is equal to $\mathrm{K}_{\mathrm{o}}, \sigma_{\mathrm{y}}$, where $\mathrm{K}_{\mathrm{o}}$ is the at rest earth pressure coefficient [10]. As a result of shear wave propagation during an earthquake, the soil receives cyclic shear stress $\left(\sigma_{h}\right)$ in the horizontal plane alternately (negative and positive direction), thus triggering rise pore water pressure.

If the total stress $(\sigma)$ does not change, the pore water pressure (u) will slowly increase and one day the pore water pressure value is equal to the total stress value. When the effective stress value is zero, sand no longer has shear strength and becomes liquefiedUsing the equation $\sigma^{\prime}=\sigma$ - uthis case can be explained by analyzing the effective stress ( $\left.\sigma^{\prime}\right)$ in the soil at a certain depth. The lateral displacement index and completion of post-liquefaction reconsolidation are considered as functions of the maximum shear strain [12].
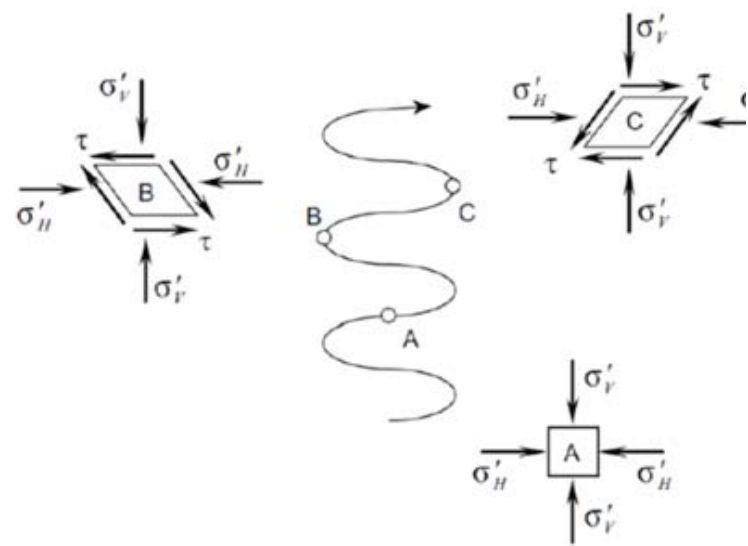

Figure 1: Stress on soil due to seismic load [11]
When soil receives seismic loads, there are two conditions that can occur: drained condition and undrained condition. Drained condition causes changes in volume in the soil, while undrained condition causes changes in pore water pressure in the soil. Under undrained condition, the gravity loads are transferred from the soil grains to the pore water.

Based on liquefaction research in several countries, it is known that co-seismic liquefaction events and the distribution of damage caused by liquefaction generally only occur in areas formed by layers of saturated granular sediment with low density, and the possibility of surface co-seismic movements exceeding the value of certain threshold [13].

Liquefaction events in the soil layer are influenced by the nature of the soil, geological conditions, and earthquake characteristics. Some factors that must be considered include grain size, groundwater level, and peak ground acceleration [13].

Research shows the hazards of liquefaction occurs due to soil material that is not easily destroyed. There are two liquefaction events that have occurred in easily destroyed soil: (1) the 1995 Hyogen-Nambu (Kobe) earthquake that occurred on January 17 with a magnitude 6,9 . The Hyogen-Nambu earthquake caused damage to airport facilities and docks on Kobe Port Island and Rokko Island.In Determining[14], (2) reclaimed islands using weak granite residual soil known as Masado soil and Shirasu soil during the 1997 Kagoshima-ken Hokuseibu earthquake, particularly Shirasu volcanic soil which was easily destroyed because the soil particles are weak [14].

\section{Soil Parameter Approach Based on CPT}

Several soil parameters can be estimated using CPT. Based on CPT, soil types can be determined as in Figure 2 and in Table 1.

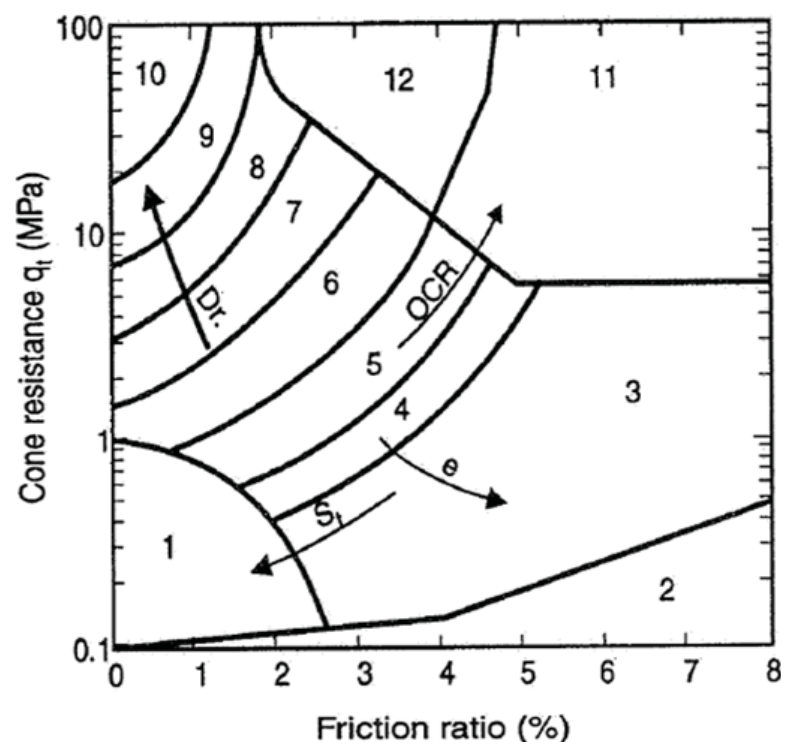

Figure 2: The relation between the value of CPT and the type of soil [15] 
Table 1: Estimation of type of soil and unit weight based on CPT [15]

\begin{tabular}{|c|c|c|}
\hline Zone & Type of Soil & $\begin{array}{c}\text { Unit Weight } \\
\left(\mathrm{kN} / \mathrm{m}^{3}\right)\end{array}$ \\
\hline 1 & Sensitive fine grained & 17,5 \\
\hline 2 & Organic material & 12,5 \\
\hline 3 & Clay & 17,5 \\
\hline 4 & Silty clay to clay & 18 \\
\hline 5 & Clayey silt to silty clay & 18 \\
\hline 6 & Sandy silt to clayey silt & 18 \\
\hline 7 & Silty sand to sandy silt & 18,5 \\
\hline 8 & Sand tosilty sand & 19 \\
\hline 9 & Sand & 19,5 \\
\hline 10 & Gravelly sand to sand & 20 \\
\hline 11 & Very stiff fine grained & 20,5 \\
\hline 12 & Sand toclayey sand & 19 \\
\hline
\end{tabular}

\section{Determination of Liquefaction Zone}

In determining the liquefaction zone, there are several parameters that can be used as a standard, such as corrected cone resistance $\left(\mathrm{q}_{\mathrm{ci}}\right)$, cyclic stress ratio (CSR), and cyclic resistance ratio (CRR). Robertson and Campanella in [15] formulated equations for corrected cone resistance $\left(\mathrm{q}_{\mathrm{ci}}\right)$ as in Equation 1.

$q_{c i}=\left(q_{c} / P_{a}\right)\left(P_{a} / \sigma^{\prime}{ }_{v o}\right)^{0,5}$

Where:

$q_{c i}=$ corrected cone resistance

$\mathrm{Pa}=$ atmospheric pressure $(100 \mathrm{kPa})$

$\sigma_{\text {vo }}^{\prime}=$ effective vertical stress

Seed and Idris in [15] formulatedthe equation to calculate the cyclic stress ratio (CSR) as in Equation 2.

$$
\operatorname{CSR}=0.65 \frac{a_{\max }}{g} \frac{\sigma_{v o}}{\sigma_{v o}^{\prime}} r_{d}
$$

Where:

CSR $=$ cyclic stress ratio

$a_{\max }=$ peak horizontal acceleration at the ground surface $\mathrm{g}=$ gravitational acceleration $\left(9.81 \mathrm{~m} / \mathrm{s}^{2}\right)$

$\sigma_{\mathrm{vo}}=$ total vertical stress

$\sigma_{\mathrm{vo}}^{\prime}=$ effective vertical stress

$r_{d}=$ stress reduction factor $(1-0.0015 z)$

$C R R=93\left(\frac{\left(q_{c 1}\right)_{c s}}{1000}\right)^{3}+0.08$

The value of soil resistance against liquefaction (CRR) is determined based on Equation 3.

References on [16] determined the zone that has the potential for liquefaction based on the graph of the relation between the CSR and $\mathrm{q}_{\mathrm{ci}}$ shown in Figure 3.

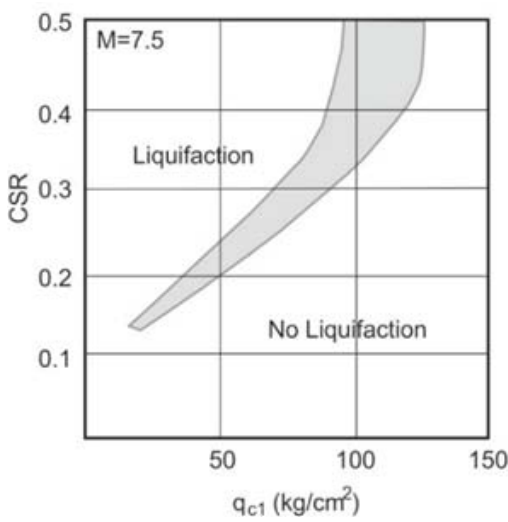

Figure 3: Potential liquefaction zones in silty sand soil [16]

\section{RESEARCH METHOD}

This research aims to assess the level of threat of liquefaction in alluvial deposits at Tukad Pancing Street, Pemogan, Denpasar. The research was conducted in Denpasar, with five drilling and CPT carried out at Jalan Taman Pancing, Denpasar as shown in Figure 4. The drilling test was carried out with a hand drill machine that belongs to the Soil Mechanics Laboratory, Civil Engineering Department, Faculty of Engineering, Warmadewa University. Lab testing is also carried out to identify the land properties needed for evaluation.

The soil profile was identified using the hand drill in every $100 \mathrm{~cm}$ and the Cone Penetration Test (CPT), reaching the subsoil at $250 \mathrm{~kg} / \mathrm{cm}^{2}$. The laboratory testing for each layer of soil includes filter analysis, unit weight, specific gravity, and direct shear test in accordance with applicable standards.

Selecting the right analysis model is needed so that the evaluation carried out closely reflects the situation in the field.

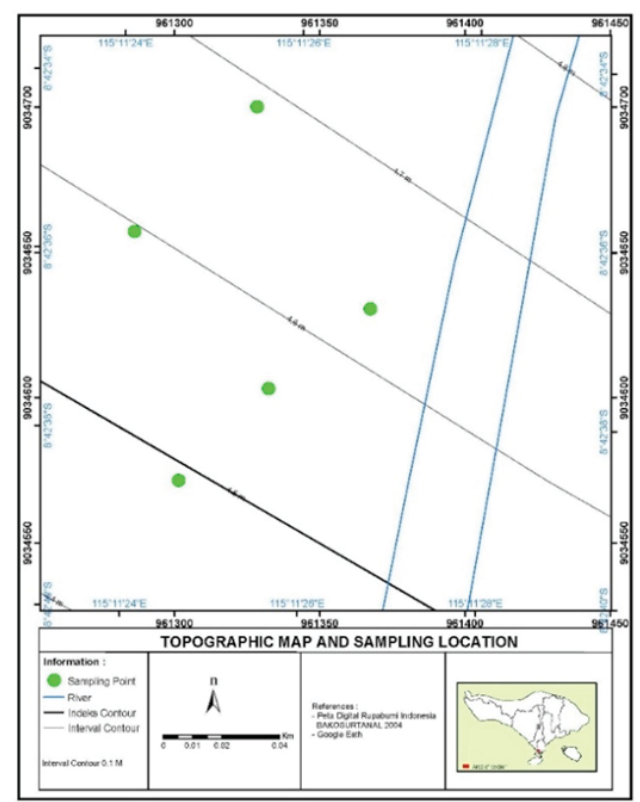

Figure 4: Topographic Map and sampling location 
The research analysis uses a simplified method model proposed by [13] and has been refined by the National Center of Earthquake Engineering Research (NCEER). The analysis uses Liquefaction Potential Index (LPI), a model proposed by Iwasaki, et all. [17], with the Japan Road Association 1990 [18] as validation.

\section{RESULTS AND DISCUSSION}

Based on the geological conditions, the land surface of Denpasar is formed from tuffs and lava deposits of

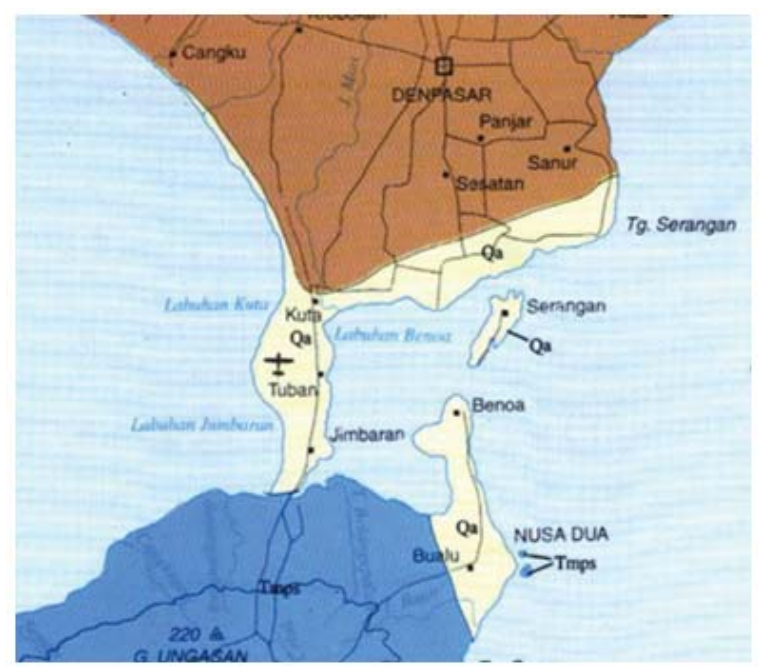

Figure 5: Geological Map of Research Location [19]
Buyan-Bratan and Batur, which is formed since 6 million years ago. The soil of the southern coastal area of Denpasar where the research was carried out, that is the Serangan village in South Denpasar was estimated to be formed from alluvium deposits. The alluvium deposits consisting of loose rocks such as sand, gravel, and clay along the Sanur and Benoa coasts are shown in Figure 5.

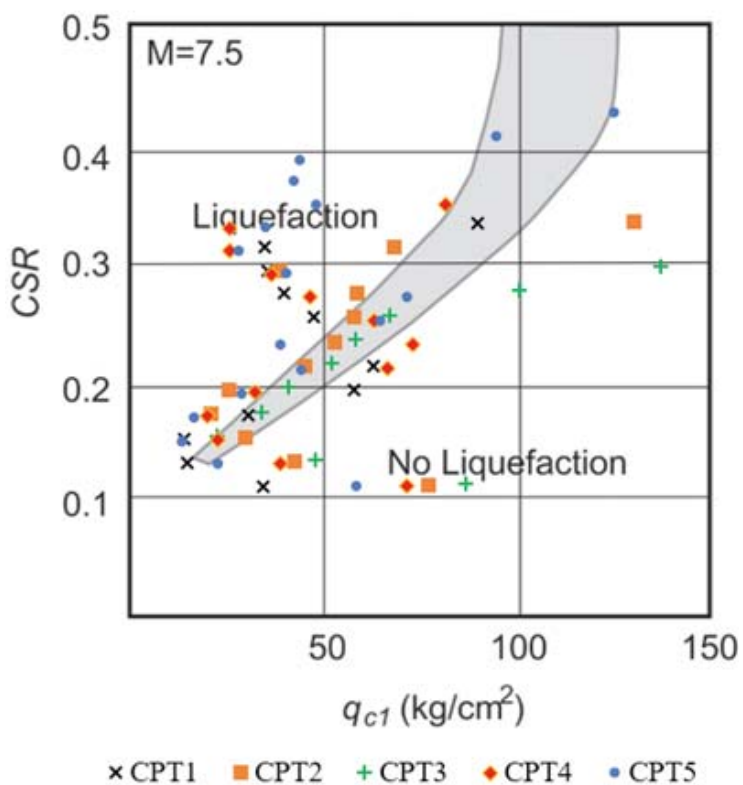

Figure 6: Potential of liquefaction

Table 2: Correlation data of CPT

\begin{tabular}{|c|c|c|c|c|c|c|c|c|c|c|c|c|c|c|c|}
\hline & & $\mathrm{CPT}$ & & & & CPT2 & & & CPT3 & & & CPT4 & & & CPT5 \\
\hline Depth & $q_{c}$ & & & $q_{c}$ & & & $q_{e}$ & & & $q_{c}$ & & & $q_{c}$ & & \\
\hline (meter) & $\left(\mathrm{kg} / \mathrm{cm}^{2}\right)$ & Zone & Type of Soll & $\left(\mathrm{kg} / \mathrm{cm}^{2}\right)$ & Zone & Type of Soll & $\left(\mathrm{kg} / \mathrm{cm}^{2}\right)$ & Zone & Type of Soil & $\left(\mathrm{kg}^{\prime} \mathrm{cm}^{2}\right)$ & Zone & Type of Soil & $\left(\mathrm{kg} / \mathrm{cm}^{2}\right)$ & Zone & Type of Soil \\
\hline 0.5 & 16.67 & 4 & Silty clay to day & 20.00 & 6 & $\begin{array}{l}\text { Sandy silt to clayey } \\
\text { silt }\end{array}$ & 25.00 & 6 & $\begin{array}{l}\text { Sandy silt to dayey } \\
\text { silt }\end{array}$ & 15.00 & 6 & $\begin{array}{l}\begin{array}{l}\text { Sandy silt to dayey } \\
\text { silt }\end{array} \\
\end{array}$ & 20.00 & 5 & $\begin{array}{l}\text { Clayey silt to silty } \\
\text { dav }\end{array}$ \\
\hline 1 & 34.00 & 6 & $\begin{array}{l}\text { Sandy silt to dayey } \\
\text { silt }\end{array}$ & 31.00 & 7 & $\begin{array}{l}\text { Silty sand to sandy } \\
\text { silt }\end{array}$ & 39.00 & 7 & $\begin{array}{l}\text { Silty sand to sandy } \\
\text { silt }\end{array}$ & 27.00 & 7 & $\begin{array}{l}\text { Silty sand to sandy } \\
\text { silt }\end{array}$ & 20.00 & 6 & $\begin{array}{l}\text { Sandy silt to clayey } \\
\text { silt }\end{array}$ \\
\hline 1.5 & 51.00 & 8 & Sand to sitty sand & 34.00 & 6 & $\begin{array}{l}\text { Sandy silt to clayey } \\
\text { silt }\end{array}$ & 55.00 & 8 & Sand to silty sand & 37.00 & 7 & $\begin{array}{l}\text { Silty sand to sandy } \\
\text { silt }\end{array}$ & 50.00 & 7 & $\begin{array}{l}\text { Silty sand to sandy } \\
\text { silt }\end{array}$ \\
\hline 2 & 46.00 & 7 & $\begin{array}{l}\text { Silty sand to sandy } \\
\text { silt }\end{array}$ & 51.00 & 7 & $\begin{array}{l}\text { Silty sand to sandy } \\
\text { silt }\end{array}$ & 64.00 & 8 & Sand to silty sand & 51.00 & 7 & $\begin{array}{l}\text { Silty sand to sandy } \\
\text { silt }\end{array}$ & 60.00 & 7 & $\begin{array}{l}\text { Silty sand to sandy } \\
\text { silt }\end{array}$ \\
\hline 2.5 & 24.00 & 7 & $\begin{array}{l}\text { Silty sand to sandy } \\
\text { silt }\end{array}$ & 54.00 & 8 & Sand to silty sand & 61.00 & 8 & Sand to silty sand & 50.00 & 7 & $\begin{array}{l}\text { Silty sand to sandy } \\
\text { silt }\end{array}$ & 35 & 5 & $\begin{array}{l}\text { Clayey silt to silty } \\
\text { day }\end{array}$ \\
\hline 3 & 11.00 & 6 & $\begin{array}{l}\text { Sandy silt to dayey } \\
\text { silt }\end{array}$ & 32.00 & 7 & $\begin{array}{l}\text { Silty sand to sandy } \\
\text { silt }\end{array}$ & 36.00 & 7 & $\begin{array}{l}\text { Silty sand to sandy } \\
\text { silt }\end{array}$ & 29.00 & 6 & $\begin{array}{l}\text { Sandy silt to dayey } \\
\text { silt }\end{array}$ & 10.00 & 3 & Clay \\
\hline 3.5 & 11.00 & 6 & $\begin{array}{l}\text { Sandy silt to clayey } \\
\text { silt }\end{array}$ & 24.00 & & $\begin{array}{l}\text { Silty sand to sandy } \\
\text { silt. }\end{array}$ & 18.00 & 6 & $\begin{array}{l}\text { Sandy silt to dayey } \\
\text { silt }\end{array}$ & 18.00 & 6 & $\begin{array}{l}\text { Sandy silt to dayey } \\
\text { silt }\end{array}$ & 10.00 & 3 & Clay \\
\hline 4 & 26.00 & 7 & $\begin{array}{l}\text { Silty sand to sandy } \\
\text { silt }\end{array}$ & 18.00 & 6 & $\begin{array}{l}\text { Sandy silt to clayey } \\
\text { silt }\end{array}$ & 29.00 & 7 & $\begin{array}{l}\text { Silty sand to sandy } \\
\text { silt }\end{array}$ & 17.00 & 5 & $\begin{array}{l}\text { Clayey silt to silty } \\
\text { clav }\end{array}$ & 10.00 & 4 & Silty day to day \\
\hline 4.5 & 52.00 & 7 & $\begin{array}{l}\text { Silty sand to sandy } \\
\text { silt }\end{array}$ & 23.00 & 6 & $\begin{array}{l}\text { Sandy silt to clayey } \\
\text { silt }\end{array}$ & 37.00 & 7 & $\begin{array}{l}\text { Silty sand to sandy } \\
\text { silt }\end{array}$ & 29.00 & 6 & $\begin{array}{l}\text { Sandy silt to dayey } \\
\text { silt }\end{array}$ & 35.00 & 5 & $\begin{array}{l}\text { Clayey silt to silty } \\
\text { day }\end{array}$ \\
\hline 5 & 60.00 & 8 & Sand to silty sand & 43.00 & 7 & $\begin{array}{l}\text { Silty sand to sandy } \\
\text { silt }\end{array}$ & 50.00 & 7 & $\begin{array}{l}\text { Silty sand to sandy } \\
\text { silt }\end{array}$ & 63.00 & 6 & $\begin{array}{l}\text { Sandy silt to dayey } \\
\text { silt }\end{array}$ & 50.00 & 7 & $\begin{array}{l}\text { Silty sand to sandy } \\
\text { silt }\end{array}$ \\
\hline 5.5 & 53.00 & 8 & Sand to silty sand & 53.00 & 7 & $\begin{array}{l}\text { Silty sand to sandy } \\
\text { silt }\end{array}$ & 59.00 & 8 & Sand to silty sand & 73.00 & 7 & $\begin{array}{l}\text { Silty sand to sandy } \\
\text { silt }\end{array}$ & 10.00 & 7 & $\begin{array}{l}\text { Silty sand to sandy } \\
\text { silt }\end{array}$ \\
\hline 6 & 50.00 & 8 & Sand to sitty sand & 61.00 & 8 & Sand to silty sand & 71.00 & 7 & $\begin{array}{l}\text { Silty sand to sandy } \\
\text { silt }\end{array}$ & 66.00 & 7 & $\begin{array}{l}\text { Silty sand to sandy } \\
\text { silt }\end{array}$ & 100.00 & 8 & Sand to silty sand \\
\hline 6.5 & 44.00 & 7 & $\begin{array}{l}\text { Silty sand to sandy } \\
\text { silt }\end{array}$ & 64.00 & 8 & Sand to silty sand & 112.00 & 8 & Sand to silty sand & 51.00 & 7 & $\begin{array}{l}\text { Silty sand to sandy } \\
\text { silt }\end{array}$ & 70.00 & 8 & Sand to silty sand \\
\hline 7 & 41.00 & 7 & $\begin{array}{l}\text { Silty sand to sandy } \\
\text { silt }\end{array}$ & 45.00 & & $\begin{array}{l}\text { Silty sand to sandy } \\
\text { silt }\end{array}$ & 160.00 & 9 & Sand & 42.00 & 7 & $\begin{array}{l}\text { Silty sand to sandy } \\
\text { silt. }\end{array}$ & 20.00 & 7 & $\begin{array}{l}\text { Silty sand to sandy } \\
\text { silt }\end{array}$ \\
\hline 7.5 & 42.00 & 7 & $\begin{array}{l}\text { Silty sand to sandy } \\
\text { silt }\end{array}$ & 83.00 & 8 & Sand to silty sand & & & & 42.00 & 7 & $\begin{array}{l}\text { Silty sand to sandy } \\
\text { silt }\end{array}$ & 30.00 & 7 & $\begin{array}{l}\text { Silty sand to sandy } \\
\text { silt }\end{array}$ \\
\hline 8 & & & & 165 & 9 & Sand & & & & 31.00 & 7 & $\begin{array}{l}\text { Silty sand to sandy } \\
\text { silt }\end{array}$ & 60.00 & 7 & $\begin{array}{l}\text { Silty sand to sandy } \\
\text { silt }\end{array}$ \\
\hline 8.5 & & & & & & & & & & 32.00 & 7 & $\begin{array}{l}\text { Silty sand to sandy } \\
\text { silt }\end{array}$ & 95.00 & 8 & Sand to silty sand \\
\hline 9 & & & & & & & & & & 106.67 & 9 & Sand & 30.00 & 8 & Sand to silty sand \\
\hline 9.5 & & & & & & & & & & 250.00 & 9 & Sand & 80.00 & 6 & $\begin{array}{l}\text { Sandy silt to clayey } \\
\text { silt }\end{array}$ \\
\hline $\begin{array}{c}10 \\
10.5\end{array}$ & & & & & & & & & & & & & $\begin{array}{l}130 \\
250\end{array}$ & $\begin{array}{l}9 \\
9\end{array}$ & $\begin{array}{l}\text { Sand } \\
\text { Sand }\end{array}$ \\
\hline
\end{tabular}


Research at Jalan Taman Pancing uses 5 CPT data with a groundwater depth of $-2.00 \mathrm{~m}$ with maximum horizontal acceleration (g) $0.44 \mathrm{~g}$. Based on CPT data correlation, the soil layer for each layer is as in Table 2. Then, the potential for liquefaction in the research area can be seen in Figure 6.

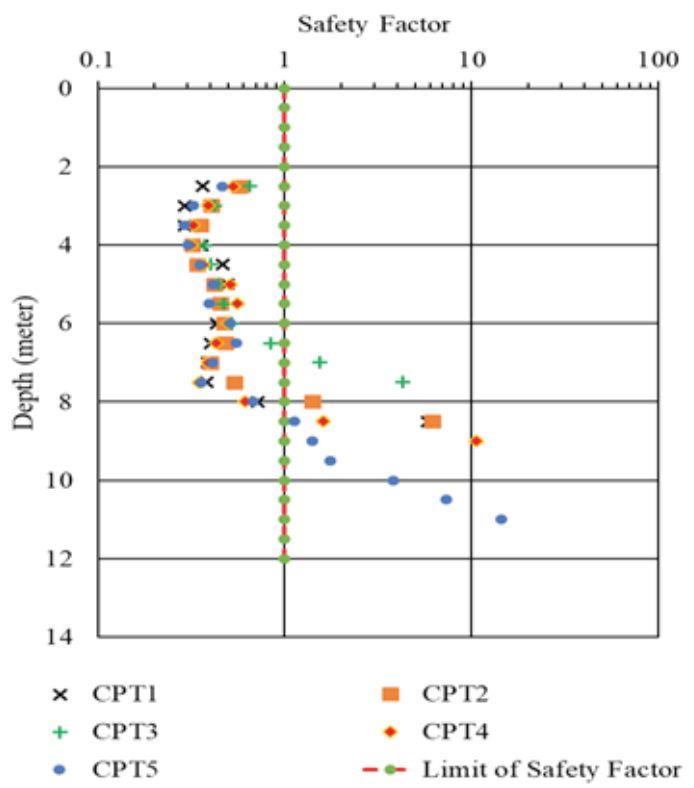

Figure 7: Safety factor based on depth

Figure 7 shows that the soil layer in the study area has a potential for liquefaction at several points, which can be seen from the point in the liquefaction zone. If considered from the safe value of liquefaction potential with the depth as in Figure 7, it can be seen that liquefaction tends to occur from a depth of $2.00 \mathrm{~m}$ to $8.00 \mathrm{~m}$ where the $q c$ cone resistance value is $q_{c}<100 \mathrm{~kg} / \mathrm{cm}^{2}$.

\section{CONCLUSION}

Based on the research on potential liquefaction carried out at Jalan Taman Pancing area using CPT data, known that in the soil at Taman Pancing has qc value ranging from $11 \mathrm{~kg} / \mathrm{cm}^{2}$ to $83 \mathrm{~kg} / \mathrm{cm}^{2}$ andthe position of the groundwater level in this area at -2.00 meter. Based on the correlation, it was known that the soil layer in the research area is mostly dominated by silty sand, which, based on the geological map in the study area, is the Qa-coded alluvium deposits due to the eruption of ancient Buyan-Beratan Mountains in the quaternary era that consists of loose rocks such as sand, gravel, and clay. When compared with the correlation made using CPT data, it shows the suitability of the interpretation of the data. From the analysis carried out using the peakhorizontal acceleration at the ground surface of $0.44 \mathrm{~g}$, it is known that the soil which has the potential to experience liquefaction is at a depth of 2.00 to 8.00 meter, considering the cone resistance value is $<100 \mathrm{~kg} / \mathrm{cm}^{2}$. With this potential in mind, there is a need to be aware of the potential for liquefaction.

\section{ACKNOWLEDGMENTS}

The authors would like to thank the Soil Mechanics Laboratory of Warmadewa University for granting permission to use the equipment. Great appreciation is also given to the Korpri Welfare Foundation of Bali Province for the financial support.

\section{REFERENCES}

1. USGS (2004) Landslide Types and Processes. Highw Res Board Spec Rep 1-4. https://doi.org/Fact Sheet 2004-3072.

2. Ishihara K, Ansal A. (1982) Dynamic Behaviour Of Soil (Soil Amplification and Soil-Structure Interaction).

3. Bhattacharya S (2013) Collapse of Showa Bridge Revisited. Int J Geoengin Case Hist 3:24-35. https:// doi.org/10.4417/IJGCH-03-01-03

4. National Earthquake Study Center (2017) Earthquake Map and Earthquake Hazards Map for Indonesia in 2017.

5. Waruwu A., C. H. Hardiyatmo, i A. Rifa'i. 2017. Deflection behavior of the nailed slab system-supported embankment on peat soil. Journal of Applied Engineering Science 15, (4): 556-563.

6. Munirwan RP, Gunawan H (2012) Evaluasi potensial likuifaksi pesisir pantai krueng raya aceh besar provinsi aceh. J Tek Sipil Univ Syiah Kuala 1:131142.

7. Sinarta IN, Rifa'i A, Faisal Fathani T, Wilopo W (2017) Slope Stability Assessment Using Trigger Parameters and SINMAP Methods on Tamblingan-Buyan Ancient Mountain Area in Buleleng Regency, Bali. Geosciences 7:110. https://doi.org/10.3390/geosciences7040110.

8. Latif DO, Rifa'i A, Suryolelono KB (2016) Chemical Characteristics Of Volcanic Ash In Indonesia For Soil Stabilization: Morphology And Mineral Content. Int J Geomate 11:2606-2610. https://doi.org/10.21660/ 2016.26.151120.

9. Sinarta IN, Rifa'i A, Fathani TF, Wilopo W (2016) Geotechnical Properties and Geologi Age on Characteristics of Landslides Hazards of Volcanic Soils in Bali, Indonesia. Int J GEOMATE 11:2595-2599. https://doi.org/10.21660/2016.26.67987.

10. Das BM (2008) Advanced Soil Mechanics, 3rd ed. Taylor \& Francis.

11. Rascol E (2009) Cyclic Properties of Sand: Dynamic Behaviour for Seismic Applications. Ecole Plytechnique Federale de Lausanne, Switzerland.

12. Ndoj A, Shkodrani N, Hajdari V (2014) Liquefaction-Induced Ground Deformations Evaluation Based on Cone Penetration Tests (CPT). World J Eng Technol 02:249-259. https://doi.org/10.4236/ wjet.2014.24026. 
13. Seed H., Idriss I. (1971) Soil Liquefactions, 1st ed. Willey Publisher, Chicago.

14. Hyodo M, Nakata Y, Aramaki N, et al (2000) Liquefaction and particle crushing of soil. 12th World Conf Earthq Eng Paper 0278 (1-8).

15. Lunne T, Robertson PK, Powell JJ. (1997) Cone Penetration Testing in Geotechnical Pratice. Blackie Academic \& Professional, London.

16. Seed H., Idriss I. (1982) Ground motions and soil liquefaction during earthquakes: engineering monographs on earthquake criteria, structural design, and strong motion records. Earthq Eng Res Institute, Oakland, Calif.
17. Iwasaki T, Arakawa T, Tokida H (1982) Simplified Procedures for Assessing Soil Liquefaction During Earthquakes. Soil Dyn Earthq Eng Conf Southampton, 925-939.

18. (JRA) JRA (1990) Specifications for Highway Bridges, Vol. V: Earthquake Resistant Design (in Japan).

19. Hadiwidjojo PM, Samodra H, Amin T. (1998) Peta Geologi Lembar Bali, Nusa Tenggara. Bandung. 